\title{
Karakteristik dan Struktur Elektronik Bahan Semikoduktor ZnO-Quantum Dot $(\mathrm{ZnO}-\mathrm{QD})$
}

\author{
Setianto $^{1}$, Liu K.M. ${ }^{2}$, Aswad H.S. ${ }^{3}$ \\ 1,2,3 Program Studi Fisika, Universitas Padjadjaran Bandung \\ 1,2,3 Jl. Raya Jatinangor KM 21, Sumedang 45363 \\ e-mail: ${ }^{1}$ setianto@phys.unpad.ac.id
}

\begin{abstract}
Abstrak - Zinc Oxide $(\mathrm{ZnO})$ merupakan bahan semikonduktor yang berupa senyawa inorganik. ZnO memiliki potensi aplikasi sebagai sensor cahaya, laser dioda, transistor film tipis transparan, dan LED (Light Emitting Diode). Celah energi pada $\mathrm{ZnO}$ dapat ditingkatkan dengan memperkecil ukuran partikel dan dikenal sebagai $\mathrm{ZnO}$ Quantum-Dot(ZnO-QD). Perhitungan celah energi ZnO-QD dengan variasi ukuran klaster ZnO dilakukan dengan menggunakan metode extended Hückel. Hasilnya menunjukkan bahwa semakin kecil ukuran klaster ZnO maka celah energi yang dihasilkan semakin besar.
\end{abstract}

Kata kunci: klaster $\mathrm{ZnO,} \mathrm{Quantum} \mathrm{dot,} \mathrm{metode} \mathrm{extended} \mathrm{Hückel}$

\section{Pendahuluan}

$\mathrm{ZnO}$ merupakan bahan semikonduktor, dengan struktur hexagonal wurtzite memiliki celah energi langsung (direct band gap) sebesar 3,37 eV. ZnO memiliki energi ikat eksiton sebesar 60 meV sehingga memungkinkan untuk emisi eksitonik yang efisien pada suhu kamar dan transparan terhadap cahaya tampak. $\mathrm{ZnO}$ memiliki potensi aplikasi untuk perangkat elektronik dan fotonik diantaranya sensor cahaya (photodetector), laser dioda, transistor film tipis transparan, dan LED (light emiiting diodes) [1, 2].

Dalam perkembangan nanoteknologi dapat dihasilkan nanopartikel dengan ukuran lebih kecil dari $100 \mathrm{~nm}$ sampai $1 \mathrm{~nm}$. Nanokristal adalah nanomaterial yang memiliki kristaltunggal dengan ukuran diameter 1-100 nm jika merupakan bahan semikonduktor disebut quntum dot [3]. Quantum dot (QD) memiliki dimensi antara molekul dengan material ukuran besar dan pada teori orbital molekul QD berada diantara molekul memiliki energi orbital yang diskrit terdapat HOMO (Highest Occupied Molecular Orbital) - LUMO (Lowest Unoccupied Molecular Orbital) dengan material ukuran besar memiliki pita energi terdapat pita valensi dengan pita konduksi [4].

Quantum dot merupakan material yang menyerap dan memancarkan cahaya secara efisien dan spesifik bergantung pada ukurannya. Pada QD terdapat pasangan elektron dan hole yang disebut eksiton. Jarak antara elektron dan hole pada bahan semikonduktor disebut dengan jarak eksiton Bohr. Pada QD mengalami efek pengurungan kuantum, tingkat pengurungan kuantum ditentukan oleh rasio antara jari-jari $\mathrm{QD}(\mathrm{R})$ terhadap jarak eksiton $\mathrm{Bohr}\left(\mathrm{r}_{\mathrm{B}}\right)$ [4]. Quantum dot $\mathrm{ZnO}$ yang mengalami efek pengurungan kuantum, memiliki diameter kurang dari $8 \mathrm{~nm}$ [5]. Pengurungan kuantum mengakibatkan meningkatnya celah energi seiring dengan penurunan ukuran QD $\mathrm{ZnO}[6,7]$. Berdasarkan hasil sintesis QD $\mathrm{ZnO}$ dengan bentuk bulat memiliki diameter $1-2,7 \mathrm{~nm}$ dan celah energi yang besarnya ditentukan oleh ukuran partikel yaitu antara 3,9 - 4,5 eV. Semakin kecil ukuran QDZnO maka celah energi yang dihasilkan akan semakin besar [7]. Terdapat 2 pendekatan teoritis untuk prediksi sifat eksiton atau QD yaitu effective mass approximation(EMA) dan Linear Combination of Atomic Orbitals (LCAO) [4].

TELKA, Vol.3 No.2, November 2017, pp. 125 130

ISSN (e): 2540-9123

ISSN (p): 2502-1982 
Seiring dengan kemajuan penerapan mekanika kuantum dalam mempelajari struktur elektronik molekul, untuk molekul yang cukup besar dapat dihitung menggunakan komputer dengan metode matematika dan analisis numerik. Perhitungan dengan komputer dapat dilakukan sesuai parameter yang tepat menggunakan persamaan Schrödinger yang tidak bergantung waktu (time-independent Schrödinger equation), solusinya merupakan fungsi gelombang dan fungsi keadaaan suatu sistem kuantum $[8,9]$.

Klaster adalah kumpulan dari partikel (atom/molekul) yang dapat dihitung. Klaster merupakan jembatan antara molekul kecil, nanopartikel dengan material ukuran besar. Dibandingkan dengan material ukuran besar, klaster menampilkan banyak sifat unik karena geometri khusus dan efek pengurungan kuantum [10]. Pada penelitian ini memodelkan QD ZnO menggunakan klaster $\mathrm{ZnO}$ yang berbentuk bulat.

Dalam penelitian ini melakukan pendekatan teoritis yaitu Linear Combination of Atomic Orbitals (LCAO) pada QD ZnO menggunakan metode extended Hückel untuk menghitung celah energi HOMO (Highest Occupied Molecular Orbital) - LUMO (Lowest Unoccupied Molecular Orbital). Menggunakan metode extended Hückel dikarenakan pada metode ini memperhitungkan semua elektron valensi dan tidak mengabaikan interaksi orbital (integral overlap) antara orbital atom [11].

\section{Metode Extended Hückel}

Orbital molekul $\mathrm{ZnO}$ dipandang sebagai Linear Combination of Atomic Orbitals (LCAO), dirumuskan :

$$
\psi=\sum_{i} c_{i} \varphi_{i}
$$

$\psi$ adalah orbital molekul, $\varphi_{i}$ adalah orbital atom dan $c_{i}$ adalah koefisien orbital atom [13]. Untuk perhitungan menggunakan metode extended Hückel digunakan matriks untuk menentukan nilai eigen yaitu energi orbital molekul dan koefisien dari orbital molekul. Metode ini menggunakan representasi matriks persamaan Schrödinger dengan Persamaan 2.

$$
\sum_{i=1}^{n}\left(H_{i j}-E S_{i j}\right) c_{i j}=0 \quad i, j=1,2, \ldots n .
$$

Dengan operator Hamiltonian pada matriks dihitung menggunakan perumusan dibawah ini:

$$
H_{i j}=0,5 K\left(H_{i i}+H_{j j}\right) S_{i j}
$$

dimana $H_{i i}$ dan $H_{j j}$ merupakan valence state ionization energy (VSIE) untuk elektron di orbital atom ke-i dan orbital atom ke-j, sedangakan $H_{i j}$ merupakan VSIE untuk elektron di orbital atom ke-i terhadap orbital atom ke-j.VSIE adalah energi yang diperlukan untuk membebaskan sebuah elektron dari atom yang sesuai dengan keadaan valensi. $S_{i j}$ merupakan integral overlap yang akan dijelaskan pada bab selanjutnya, harga parameter $\mathrm{K}=1,75$ yang disarankan oleh Hoffmann. Persamaan 2 diselesaikan untuk memperoleh energi orbital molekul (E) dan koefisien-koefisien dari orbital molekul $\left(c_{i j}\right)[14,15]$.

Pada penelitian penelitian ini menggunakan kristal $\mathrm{ZnO}$ hexagonal wurtzitedengan space group P63mc; dengan nilai parameter kisi $a=b=3,24 \times 10^{-10} \mathrm{~m}, c=5,20 \times 10^{-10} \mathrm{~m} ; \alpha=\beta=90^{\circ}$ dan $\gamma=120^{\circ}$; dengan 2 atom $\mathrm{Zn}$ dan 2 atom $\mathrm{O}$ setiap primitive cell [parameter kisi]. Untuk membuat suatu molekul dengan jumlah ion yang lebih banyak maka dapat dilakukan duplikasi dengan teknik translasi untuk menghasilkan sel satuan yang identik dengan operasi dengan persamaan $\mathrm{T}=\mathrm{n}_{1} \mathrm{a}+\mathrm{n}_{2} \mathrm{~b}+\mathrm{n}_{3} \mathrm{c}$ dimana $\mathrm{n}_{1}, \mathrm{n}_{2}$ dan $\mathrm{n}_{3}$ adalah bilangan bulat, $\mathrm{a}, \mathrm{b}$ dan $\mathrm{c}$ adalah vektor satuan dalam arah 3 dimensi. lalu di supercell agar menghasilkan kristal hexagonal wurtzite dengan jumlah ion yang lebih banyak. Sehingga didapatkan model klaster ZnO. 


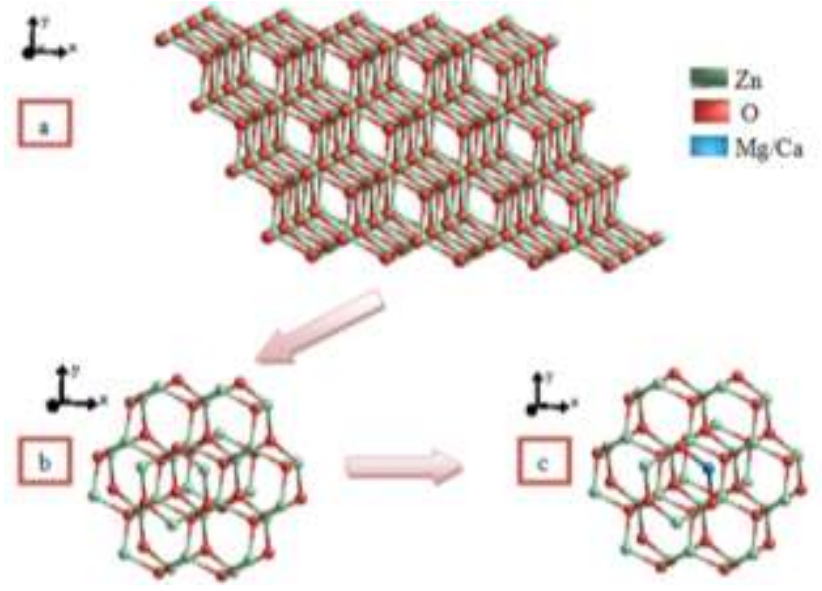

Gambar 1. Langkah pembuatan model klaster $\mathrm{ZnO}$ murni dan terdoping

Pada Gambar 1.a adalah model klaster $\mathrm{ZnO}$ dalam bentuk kotak, untuk mendapatkan model klasterZnO murni pada Gambar 1.b dibuat dengan menghapus satu persatu atom pada Gambar 3.2.a sehingga terbentuk model klaster ZnOdengan bentuk bulat.Pada model klasterZnO murni, Gambar 1.b akan divariasikan ukurannya. Perhitungan numerik menggunakan ArguLab dengan metode extended Huckel [16-20]

\section{Hasil dan Pembahasan}

Pada penelitian ini dibuat model klaster $\mathrm{ZnO}$ murnidengan bentuk bulat yang ukurannya akan divariasikan antara $0,9 \mathrm{~nm}$ sampai 2,6 $\mathrm{nm}$.

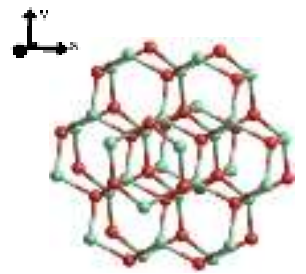

(a)

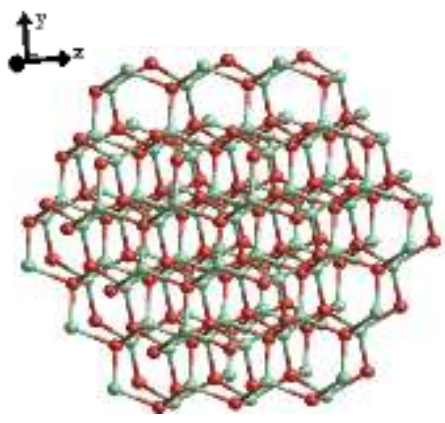

(c)

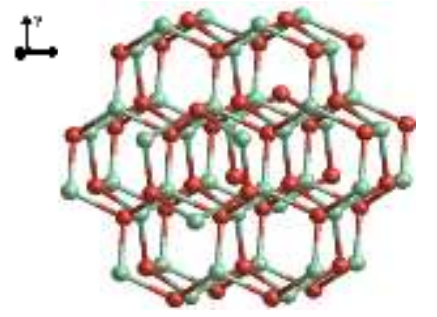

(b)

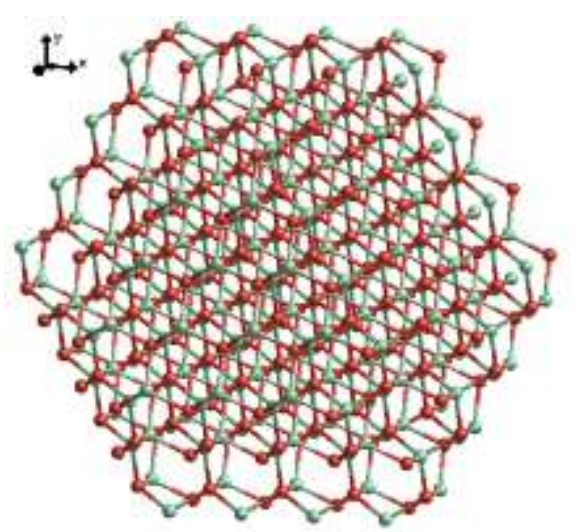

(d)

Gambar 2. Model klaster $\mathrm{ZnO}$ : (a) $(\mathrm{ZnO})_{30}$; (b) $(\mathrm{ZnO})_{42}$; (c) $(\mathrm{ZnO})_{102}$; (d) $(\mathrm{ZnO})_{234}$ 
Variasi diameter model klaster $\mathrm{ZnO}$ murni pada penelitian ini berukuran dari $0,9174 \mathrm{~nm}$ sampai 2,6467 $\mathrm{nm}$. Hasil perhitungan berdasarkan variasi ukuran model klaster $\mathrm{ZnO}$ murni disajikan pada Tabel 1 berikut ini.

Tabel 1. Hasil celah energi model klasterZnO murni

\begin{tabular}{ccccc}
\hline Klaster & Diameter $(\mathbf{n m})$ & $\boldsymbol{E}_{\text {HOMO }}(\boldsymbol{e V})$ & $\boldsymbol{E}_{\boldsymbol{L U M O}}(\boldsymbol{e V})$ & $\Delta \mathbf{E}_{\mathrm{HL}}(\mathbf{e V})$ \\
\hline$(\mathbf{Z n O})_{\mathbf{3 0}}$ & 0,9174 & $-14,763636$ & $-11,605682$ & 3,157954 \\
$(\mathbf{Z n O})_{\mathbf{4 2}}$ & 1,0041 & $-14,760863$ & $-11,605656$ & 3,155207 \\
$(\mathbf{Z n O})_{\mathbf{1 0 2}}$ & 1,4937 & $-14,606205$ & $-11,606205$ & 3,148452 \\
$(\mathbf{Z n O})_{\mathbf{2 3 4}}$ & 2,0704 & $-14,752846$ & $-11,608073$ & 3,144773 \\
$(\mathbf{Z n O})_{\mathbf{2 9 7}}$ & 2,2435 & $-14,752734$ & $-11,608749$ & 3,143850 \\
$(\mathbf{Z n O})_{\mathbf{3 5 0}}$ & 2,6467 & $-14,751103$ & $-11,608398$ & 3,142705 \\
\hline
\end{tabular}

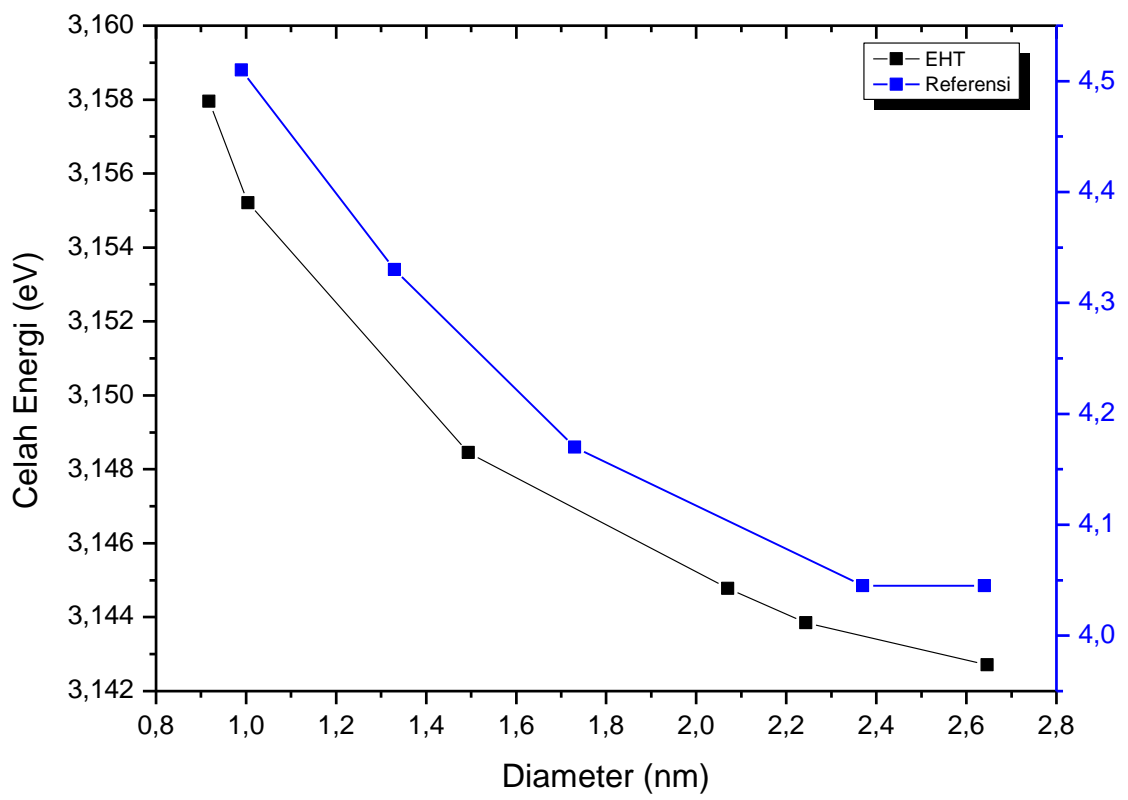

Gambar 3.Grafik pengaruh diameter partikel $\mathrm{ZnO}$ terhadap celah energi [5]

Tabel 1 diatas menunjukkan bahwa nilai celah energi HOMO-LUMO dari energi orbital molekul ditentukan oleh besarnya diameter model klasterZnO.Semakin kecil diameter klaster $\mathrm{ZnO}$ maka semakin besar celah energi yang dihasilkan. Pada Gambar 3 merupakan grafik celah energi terhadap diameter partikel $\mathrm{ZnO}$ dari hasil perhitungan EHT dan hasil eksperimen. Kotak warna bitu pada Gambar 3 adalah data dari referensi hasil sintesis QDZnO dan kotak warna hitam adalah hasil dari perhitungan EHT.

Hasil perhitungan EHT nilainya tidak sama dengan hasil eksperimen, akan tetapi trend data menunjukkan hasil yang sama. Hal ini disebabkan oleh karena nilai konstanta (K) yang digunakan pada perhitungan EHT sebesar 1,75 sesuai yang dianjurkan oleh Hoffmann [20]. Nilai 1,75 yang dianjurkan oleh Hoffmann tersebut merupakan hasil evaluasi pada etana $\left(\mathrm{C}_{2} \mathrm{H}_{6}\right)$. Nilai $\mathrm{K}$ yang seharusnya digunakan pada perhitungan EHT tersebut harus cocok dengan energi total yang berkaitan dengan gaya tarik inti dan elektron $\mathrm{ZnO}$. Akan tetapi belum ada penelitian menentukan konstanta (K) pada perhitungan EHT untuk ZnO. 


\section{Kesimpulan}

Perhitungan celah energi pada model klaster $\mathrm{ZnO}$ murni dan klasterZnO terdoping menggunakan metode extended Hückel telah dilakukan. Untuk model klaster $\mathrm{ZnO}$ murni dengan ukuranpartikel $0,9 \mathrm{~nm}$ sampai 2,6 $\mathrm{nm}$ berbentuk bulatdidapatkan hasil celah energi klasterZnO yang dipengaruhi oleh ukuran klasteryaitu semakin kecil ukuran klasterZnO maka celah energi yang dihasilkan akan semakin besar. Pada penelitian ini terdapat parameter perhitungan yang kurang tepat yaitu konstanta $\mathrm{K}$ sebesar 1,75 tidak cocok untuk ZnO.

Rekayasa celah energi pada $\mathrm{ZnO}$ dapat dilakukan dengan memperkecil ukuran quantum dot (QD) $\mathrm{ZnO}$ sehingga celah energi yang didapatkan meningkat diiringi dengan penurunan ukuran (QD) $\mathrm{ZnO}$.

\section{Daftar Pustaka}

[1] A. Janotti, C. G. Van de Walle, Fundamental of zinc oxide as a semiconductor, Rep. Prog. Phys. 72 (2009) 126501 (29pp).

[2] L.W. Zhong, Zinc oxide nanostructures: growth, properties and Applications, Journal ofPhysics : condensed matter 16 (2004) R829-R858.

[3] H.Haberland (ed.), Cluster of Atoms and Molecules, Springer-Verlag, Berlin. 1995.

[4] R. Moreno, B. Ferrari, Nanoparticles Dispersion and the Effect of Related Parameters in the EPD Kinetics. Electrophoretic Deposition of Nanomaterials Nanostructure Science and Technology 2012, Springer, pp 73-128.

[5] A. Wood, M. Giersig, M. Hilgendorff, A. Vilas-Campos, L. M. Liz-Marzan, and P. Mulvaney. Size Effects in ZnO: The Cluster to Quantum Dot Transition. Australian Journal of Chemistry56(10) 1051-1057.

[6] B.Debasis, Q.Lei, Teng-Kuan, Paul.H. Quantum Dots and Their Multimodal Aplications :ARreview.Materials, vol. 3, issue 4, pp. 2260-2345. 2010

[7] J.Daudien, Sintesis Partikel ZnO Terdoping dengan Metode Spray Pyrolisis, Skripsi Program Studi Fisika Material-Jurusan Fisika, Fakultas Matematika dan Ilmu Pengetahuan Alam, Bandung. 2012

[8] G.G.Hall, Application of Quantum Mechanics in Theoretical Chemistry, Reports on Progress in Physics vol 22 (1959).

[9] I. N. Levine, Quantum Chemistry $5^{\text {th }}$ Edition, Prentice Hall, 2000.

[10] H. Haberland (ed.), Cluster of Atoms and Molecules, Springer-Verlag, Berlin, 1995.

[11] R.E. Siregar,Diktat Kuliah :Mekanika Kuantum Molekul, Fisika Unpad.

[12] J.Daudien, Sintesis Partikel ZnO Terdoping dengan Metode Spray Pyrolisis, Skripsi Program Studi Fisika Material-Jurusan Fisika, Fakultas Matematika dan Ilmu Pengetahuan Alam, Bandung, 2012.

[13] R.E. Siregar,Diktat Kuliah :Mekanika Kuantum Molekul, Fisika Unpad, 2004.

[14] John P. Lowe, Kirk A. Peterson. Quantum Chemistry, Third Edition. Elesevier Academic Press. London, 2005.

[15] R. Hoffmann, An extended Hückel theory. I. hydrocarbons. J. Chem. Phys. 39 (6) : $1397-$ $1412,1963$.

[16] Thompson, M. A., Software ArgusLab, Tersedia online : http://www.arguslab.com/arguslab.com/ArgusLab.html (diakses pada tanggal 7 Agustus 2012)

[17] M. A.Thompson,M. C. Zerner,Teoritical examination of the electronic structure and spectroscopy of the photosynthetic reaction center from Rhodopseudomonasvirdis. J. Am. Chem. Soc., 113, 8210-8215, 1991.

[18] Mark A. Thompson, Eric D. Glendening, David Feller. The nature of K+/Crown Ether interactions : A hybrid quantum mechanical-molecular mechanical study. J.Phys. Chem., 98, 10465-10476, 1994. 
[19] M. A. Thompson, Gregory K. Schenter.Excited states of the bacteriochlorophyll b dimer of Rhodopseudomonasviridis: A QM/MM study of the photosyntheticreactioncenter that includes MM polarization. J. Phys. Chem., 99 (17), 6374-6386, 1995.

[20] M. A. Thompson. QM/MMpol : A consistent model for solute/solvent polarization. application to the aqueous solvation and spectroscopy formaldehyde, acetaldehyde, and acetone. J. Phys. Chem., 100, 14492 - 14507, 1996.

[21] K.Y. Manoj, G. Manoranjan, Band-gap variation in Mg-and Cd-doped ZnO nanostructures and molecular cluster. Physical Review B 76, 195450, 2007.

[22] D. K. Hwang, M. C. Jeong, J. M. Myoung, Effect of deposition temperature on the properties of $\mathrm{Zn}_{1-x} \mathrm{Mg} g_{x} \mathrm{O}$ thin films. Applied Surface Science, 225, 217-222, 2004. 